\title{
Reminiscência e Registro: um estudo da produção memorialística dos jornalistas da revista Realidade
}

Vaniucha de Moraes $^{2}$

Resumo: Este artigo aborda a produção memorialística de jornalistas que compuseram a primeira equipe da extinta revista Realidade (1966/1968). Tais jornalistas tiveram seus relatos biográficos registrados em pesquisas científicas a partir dos anos 1990 e obtiveram prestígio no meio intelectual nos anos 2000, década em que começaram a publicar autobiografias e livros de memórias. A motivação para a presente discussão consiste em investigar a relação entre o registro dessas narrativas e o contexto social e histórico em que foram produzidas.

Palavras-Chave: Elite Jornalística, História do Jornalismo, Sociologia da Cultura.

\section{Reminiscence and record: a study of memoirs productions of the Reali- dade magazine's journalists}

Abstract: This work discusses the memoirs of the journalists who composed the first team of the extinct Realidade magazine (1966/1968). Those journalists had their biographical accounts recorded in scientific researches from the 90 and gained prestige in intellectual circles in the 20oos, the decade that they began to publish

\footnotetext{
1 O presente trabalho foi realizado com apoio do Conselho Nacional de Desenvolvimento Científico e Tecnológico - $\mathrm{CNPq}$ - Brasil.

2 Programa de Pós-Graduação em Sociologia e Política da Universidade Federal de Santa Catarina (UFSC) Florianópolis - Brasil - ucha8@outlook.com
} 
autobiographies and memoirs. The motivation for this discussion is to investigate the relationship between the recording of these narratives and socio-historical context in which they were produced.

\section{Keywords: Journalistic elite; Journalism History; Sociology of Culture.}

A primeira década do século XXI foi, para muitos jornalistas, um período de recebimento de homenagens às experiências profissionais realizadas há 40 anos. Após quatro décadas, os jornalistas que integraram a redação da revista Realidade começaram a lançar no mercado editorial suas biografias e memórias. O saudosismo dos últimos anos foi antecedido por uma série de trabalhos acadêmicos produzidos uma década antes, nos anos 90. Tais trabalhos saudavam a publicação, posicionando-a no panteão das principais experiências da história da imprensa nacional - um marco da reportagem brasileira - e de certa maneira ensejaram a produção memorialística.

A investigação da produção memorialística e biográfica dos jornalistas da extinta revista Realidade foi motivada por aspectos relacionados às seguintes questões: a relação entre as condições de produção dos livros de memórias e biografias e o momento de mudanças no mercado profissional jornalístico nos anos de 1960 a 2010 e o contexto social e histórico brasileiro; a interação entre as origens e trajetórias sociais dos jornalistas memorialistas e as transformações no âmbito da produção cultural, especialmente no jornalismo; e, por fim, o papel desempenhado pelo gênero textual da reportagem na configuração de um modelo de jornalista a ser consagrado. Essas questões impulsionaram o presente estudo a investigar as inter-relações entre as reminiscências e os registros jornalísticos.

Preliminarmente, pode-se destacar que a especificidade da produção memorialística dos jornalistas em questão consiste no estilo textual empregado e no prestígio do posicionamento dos autores na hierarquia do jornalismo. São obras que se caracterizam pela abordagem de trajetórias de vida em congruência com a história da imprensa brasileira e do país. Elas contam a história de indivíduos que vivenciaram uma série de acontecimentos significativos, como as transformações no mercado profissional e os embates com a censura imposta pelo regime militar nos anos 1960 e 1970. Em muitas dessas publicações, pode-se encontrar a reprodução de reportagens publicadas primeiramente na revista Realidade (1966-1968) e também nos jornais da imprensa alternativa (1970), produções que conquistaram prestígio ao serem revisitadas por pesquisas acadêmicas a partir dos anos 1990. Outra particularidade da 
produção memorialística está vinculada à posição consagrada de seus autores, ex-repórteres da revista Realidade e autores de livros-reportagens. A referência à reportagem não é gratuita. Texto apoiado em pesquisa de profundidade, mais extenso que os demais textos noticiosos, escrito em estilo testemunhal e literário, a reportagem é o gênero jornalístico por excelência dentro da historiografia da profissão.

A produção biográfica e memorialística dos jornalistas consagrados se define pelas marcas autorais que explicitam e pela remissão ao gênero da reportagem. Portanto, trata-se de um estilo que se diferencia do padrão noticioso de outro gênero textual: a notícia, essa caracterizada pela objetividade e pela imparcialidade. Cumpre esclarecer que a notícia se caracteriza também pela concisão e ausência de marcas autorais e se contrapõe à reportagem, plena de marcadores de autoria e referências literárias. Por sua vez, a distinção entre 0 texto noticioso - a notícia - e o texto autoral - a reportagem - remonta ao conflito geracional instaurado no meio profissional com a entrada de uma nova geração de jornalistas egressos da universidade após a exigência do diploma para o exercício da profissão em 1969. Esse novo requisito desencadeou um conflito entre "antigos" e "novos" jornalistas, cujo auge se deu nos anos 1980 e 1990. Em outras palavras, gerou o embate entre os autodidatas - formados pela vivência nas redações e pela luta contra a censura durante o regime ditatorial - e os diplomados, jovens profissionais que ingressaram na profissão trazendo consigo uma visão técnica e menos ideológica acerca do ofício. Em meio à disputa por posições de maior autoridade e autonomia, os neófitos na profissão logo foram rotulados como acríticos e burocratas pelos veteranos. Esse é o cenário no qual surgiram as distinções textuais anteriormente apontadas e no qual a linguagem tornou-se o campo de batalha. A redação da notícia era destinada aos recém-chegados enquanto a reportagem era reservada aos detentores de maior prestígio, pois a posição de autor destinava-se aos notáveis. Isto é, a desigualdade estrutural entre as posições na hierarquia profissional se equipara às desigualdades entre os textos produzidos por eles, suas designações de autoria, os valores documentais de seus registros e também a desigualdade presente nas memórias da profissão (Bergamo, 2014: 227).

Nas biografias e memórias, reportagens que haviam sido publicadas primeiramente em jornais e revistas foram recorrentemente reproduzidas na íntegra. A remissão a essas reportagens pode ser compreendida ao se considerar o valor que possuem no âmbito profissional. A reportagem é considerada a essência do jornalismo, uma vez que nela se encerram as características fundamentais do modelo profissional consagrado pela vivência em contraposição à formação 
universitária. As características da reportagem, como a presença de marcas autorais, a fusão entre a memória individual e a memória coletiva (do mundo, do país ou da imprensa), estabelecem uma relação intrínseca com a identidade clássica da profissão. A reportagem, autoral e literária, contrapõe-se à notícia, texto conciso produzido em linguagem referencial e destituído de marcas de autoria. A produção e assinatura de uma reportagem são reservadas à elite profissional enquanto a notícia é destinada aos denominados "focas" ou calouros da redação. Por isso, a reportagem e sua reprodução em livros de memórias e biografias de jornalistas veteranos pode ser situada no conflito em torno da definição da história e da memória profissional. Pode-se considerar, ainda, que enquanto a notícia é considerada parte de uma produção em série, feita para ser consumida e logo descartada, a reportagem é feita para ser lida mais de uma vez (Bergamo, 2014), o que corrobora para sua republicação em livro décadas depois da primeira publicação em jornais e revistas.

No artigo, busco contemplar a visão de que a produção memorialística é um elemento privilegiado para a compreensão de estratégias e princípios de afirmação e hierarquização, bem como está envolvida diretamente na busca pelo monopólio da representação legítima e induz à compreensão do funcionamento de determinado âmbito da produção cultural, nesse caso, o mercado profissional jornalístico. Aqui também considero o valor da produção autobiográfica para profissionais da escrita, como os jornalistas, para quem a transformação da trajetória pessoal e profissional em capital simbólico representa muito em termos de possibilidade de consagração e legitimação (Miceli, 2001; Pontes, 2003; Grill, 2012b).

O percurso da análise começa pela abordagem dos trabalhos acadêmicos a respeito da revista Realidade e de seus protagonistas, seguido pelo despertar do interesse pela produção de memórias por parte dos jornalistas; na sequência, trato da relação indistinta entre memória individual e memória coletiva; em seguida, analiso as origens e trajetórias sociais para exemplificação das mudanças no mercado profissional jornalístico; e, por fim, concentro-me nos elementos que foram silenciados no processo de edificação da produção memorialística no que se refere à formação intelectual refletida no repertório e no estilo de escrita.

\section{Interesse acadêmico: a revista Realidade nos dias atuais}

A produção científica realizada a partir dos anos 1990 a respeito dos jornais e revistas que se destacaram nas décadas de 1960 e 1970 contou com a colaboração de vários jornalistas que concederam entrevistas a pesquisadores 
de diversas áreas do conhecimento. Uma parcela dessas pesquisas tinha como objeto e fonte a revista Realidade (1966-1968) e os periódicos da chamada imprensa alternativa dos anos $1970^{3}$.

A revista Realidade, primeira experiência da Editora Abril em publicações de informação geral, existiu por dez anos consecutivos, de 1966 a 1976. Seu auge, porém, foram os primeiros anos, de 1966 a 1968, período em que chamou atenção pela ousadia na linguagem e na temática. Em sintonia com a efervescência cultural daquele momento, a revista abordou toda sorte de polêmicas que agitavam os anos 1960. Era essencialmente uma revista de reportagens. Grande parte delas redigidas em primeira pessoa e resultantes de pesquisas de imersão. Plenas de marcas autorais, as reportagens de Realidade remontam às impressões pessoais do repórter e ao intercurso vivido nas suas produções.

Realidade se beneficiou dos estertores do intervalo democrático para contestar a moral vigente e o Estado autoritário em gradativo recrudescimento do golpe militar. Isto é, no auge da revista, o Ato Institucional n. 5 ainda não havia sido promulgado. A partir da segunda metade do ano de 1968, entretanto, a equipe responsável pela linha editorial adotada já se encontrava fragmentada em função do contexto de pressão política. Após 1968, Realidade sofreu um gradativo processo de descaracterização de seu projeto inicial. Teve reduzido o número de tiragens até finalmente parar de ser impressa em 1976. Porém, os momentos áureos de Realidade, de 1966 a 1968, permaneceram na memória dos profissionais de imprensa, dos leitores e, sobretudo, nas mentes daqueles que se encarregaram de fixá-la nos registros da história da imprensa brasileira por meio de autobiografias e trabalhos científicos.

A revista Realidade motivou muitos trabalhos acadêmicos ${ }^{4}$. A lista de pesquisas que direta ou indiretamente abordaram a referida publicação inclui trabalhos realizados, sobretudo, por pesquisadores que tiveram formação inicial em jornalismo, atuaram como jornalistas ou são professores na área de Comunicação Social e Jornalismo, como Maria Terezinha Tagé, Edvaldo Pereira Lima,

3 Neste trabalho analiso depoimentos de jornalistas que integraram a primeira equipe da revista Realidade (1966/1968) e fizeram parte dos jornais alternativos Bondinho (1970), Jornalivro (1971), Grilo (1971), Fotochoq (1973), Ex (1973), Movimento (1975) e Extra-Realidade Brasileira (1976).

4 Jorge Andrade, Repórter Asmodeu: leitura do discurso jornalístico de autor na revista Realidade, de Maria Terezinha Tagé Dias Fernandes (tese de doutorado, ECA-USP, 1988). O livro-reportagem como uma extensão do jornalismo impresso: realidade e potencialidade, de Edvaldo Pereira Lima (tese de doutorado, ECA-USP, 1993). Realidade 1966-1968: tempo de reportagem na imprensa brasileira, de José Salvador Faro (tese de doutorado, ECA-USP, 1999). A dança efêmera dos leitores missivistas na revista Realidade, de Letícia Nunes Goés (dissertação de mestrado, FFLCH-USP, 2001). Entre o sonho e a realidade: pioneirismo, ascensão e decadência da revista Realidade (1966-1976), de Adalberto Leister Filho (dissertação de mestrado, FFCH-USP, 2003). 
José Salvador Faro, Letícia Nunes Goés e Adalberto Leiter Filho, por exemplo. Ao compulsar as biografias e memórias pude perceber que enquanto Realidade conquistava cada vez mais prestígio como objeto de pesquisa no âmbito acadêmico, os jornalistas que fizeram Realidade também redigiam seus livros de memórias. Assim, o que o conjunto das obras mostra é a convergência entre os interesses de pesquisa dos acadêmicos e a vontade de testemunhar dos sujeitos históricos.

No que concerne aos livros de biografias e memórias, cumpre destacar na presente análise que esses registros exerceram a função de difundir um modelo profissional de jornalista a ser considerado legítimo. Tendo em vista que o moderno jornalismo concede outro tratamento à autoria, posso inferir que os jornalistas remanescentes de Realidade se dedicaram a redigir suas memórias em outros suportes (livros-reportagens ao invés de periódicos), possivelmente tendo em mente outros públicos-alvos, por exemplo, o público universitário. Nesta produção memorialística é evidente a remissão a um modelo de profissional a ser seguido. As biografias e memórias procuram responder à questão sobre 0 que é ser jornalista e terminam por esculpir em palavras um modelo de profissional consagrado 5 . Faz sentido se considerarmos que esse padrão de atuação foi internalizado pelos memorialistas no início de suas prestigiadas carreiras nos anos 1960. Nas décadas seguintes, embora afastados de altos cargos, alguns dos remanescentes de Realidade souberam canalizar talento para a imprensa alternativa e outras produções que atendiam a nichos de mercado. Em revistas, jornais ou livros-reportagens e memorialísticos, empreenderam a edificação da legitimidade de um tipo de profissional de imprensa. Esse padrão de consagração identificado com a identidade do jornalista engajado e escritor de livros-reportagens ainda que estivesse em contradição com o moderno jornalismo, fez com que esses memorialistas conquistassem o reconhecimento por parte dos intelectuais, escritores e pesquisadores. Fato esse que lhes garantiu a condição de autores e intelectuais prestigiados no campo da produção cultural brasileira.

\section{Memória e história de Realidade: a individual e a coletiva}

No que concerne à historiografia da imprensa, era comum até a época em que Realidade circulava como publicação mensal da Editora Abril, que a história do país, documentada em jornais e revistas, estivesse de certa forma atrelada à

5 O modelo profissional que conjuga o trabalho na imprensa, o engajamento político e o "flerte" com a literatura pode ser identificado no livro A notícia: um produto à venda: jornalismo na sociedade urbana e industrial, de Cremilda Medina, e A regra do jogo - o jornalismo e a ética do marceneiro, de Cláudio Abramo, ambos datados de 1988. 
história de suas testemunhas oculares, os repórteres. A linguagem jornalística padronizada ainda não havia sido adotada em veículos de periodicidade estendida e, por isso, na revista Realidade, várias reportagens vinham registradas com a marca autoral. Era recorrente o emprego de recursos literários, como a primeira pessoa do singular e as figuras de linguagem. A publicação chegou a veicular o gênero reportagem-conto que consistia em matérias nas quais um personagem real era selecionado para protagonizar determinado assunto, mostrando a dimensão épica da vida de pessoas comuns por meio de recursos literários. Entretanto, após o momento em que a atividade jornalística tornou-se mais técnica, a reportagem literária tornou-se cada vez mais restrita aos livros-reportagens e revistas especializadas. A mudança no mercado profissional e o efeito da própria conjuntura política e social resultaram na migração de muitos profissionais para a imprensa alternativa durante a década de 1970. Os livros-reportagens se tornaram uma forma de fugir da censura que imperava nos meios de comunicação.

Nesse contexto, muitos jornalistas exploraram o formato para realizar narrativas de não-ficção destinadas a públicos específicos e intelectualizados. Atualmente, entre os entrevistados dessa pesquisa, muitos ainda participam de projetos alternativos. Além de publicarem livros de grandes reportagens e obras sobre suas memórias profissionais, tais produções se integram às principais fontes da presente pesquisa.

João Antônio, escritor e jornalista de Realidade, já havia publicado na coletânea de contos Malhação do Judas Carioca, de 1975, uma reportagem-conto sobre o cotidiano do cais de Santos, intitulado Cais e originalmente publicado sob o título Um dia no cais, na edição de novembro de 1968 de Realidade. Em 2005, João Antônio foi biografado por Mylton Severiano, amigo e companheiro dos tempos de Realidade, em Paixão de João Antônio. Os exemplos mostram a simbiose entre produção jornalística e literária e a permeabilidade entre seus agentes. Antes, porém, em 1998, José Hamilton Ribeiro publicou o livro Jornalistas: 1937 a 1997 - história da imprensa de São Paulo vista pelos que batalham laudas (terminais), câmeras e microfones, livro que marcava o aniversário de 60 anos do Sindicato dos Jornalistas de São Paulo, no qual consta uma sucinta referência à Realidade.

Após o ano de 2005, ano da publicação da biografia sobre João Antônio, Mylton Severiano e os remanescentes receberam ainda mais pesquisadores e Realidade consolidou seu prestígio com a contribuição dos trabalhos acadêmicos que a revisitaram. Diante da profusão dos trabalhos científicos publicados e dos constantes contatos para entrevistas, vários remanescentes da publicação tomaram a iniciativa de contar suas próprias histórias. Os livros que tratam das 
memórias e biografias, assim como os relatos biográficos obtidos em entrevistas, apresentam uma perspectiva de fusão entre vida pessoal, profissional e do grupo formado em Realidade e que prosseguiu relativamente unido durante $\mathrm{o}$ período da imprensa alternativa.

Tais obras consistem na narrativa de um indivíduo inserido em seu grupo, entremeada com a história da imprensa e do país. Destaco ainda que Realidade e alguns de seus protagonistas também fundaram projetos de comunicação, como a Caros Amigos, em 1997. A revista publicou, em maio de 2008, uma edição especial em memória a Sérgio de Souza, falecido naquele ano. Sérgio havia sido editor de texto de Realidade e, na década de 1970, capitaneou várias produções da imprensa alternativa, sendo uma referência para os amigos e motivo para a dedicação de uma edição integral a ele.

Outra característica dos relatos memorialísticos dos profissionais consiste na fusão entre as histórias pessoais, profissionais e a história do país. Há a referência ao declínio da revista diante da escalada do golpe militar e da censura, pois tiveram repercussão direta nas vidas pessoais e profissionais desses jornalistas, uma vez que os orientaram para outra opção de imprensa que posteriormente foi adequadamente intitulada como "alternativa". O momento de efervescência cultural e política da década de 1960 é também sempre relembrado como gatilho para forma de expressão jornalística que gerou Realidade. É o caso de Carlos Azevedo, que assim menciona o período de aglutinação de jornalistas para formação da equipe:

Enfim, era uma turma que não tinha tempo a perder, sentia a urgência de participar daquele mundo em transformação, que, achávamos, seria dos jovens e nunca mais seria o mesmo, que haveria de ser melhor, de mais igualdade, e aí morava o nosso engano (...) viemos por caminhos diversos até Realidade, e essa riqueza de experiências resultou num produto surpreendente, maior que todos (Azevedo, 2007a: 105).

A narrativa de Azevedo, semelhante à dos demais memorialistas, enfatiza um modelo profissional de jornalista. Nessas narrativas, evidencia-se a imagem do jornalista combativo diante da história do mundo que se desdobra diante de si e da qual faz parte. Desses relatos também emerge a ideia de que a revista e o grupo são indistintos e, por serem tratados como uma coisa só, ao se reiterar o prestígio da publicação, consagra-se tanto o grupo como o profissional que narra suas experiências após o transcorrer de quatro décadas, período em que a mística em torno da revista Realidade foi sendo paulatinamente construída por pesquisadores. 
Nota-se que os livros mencionados possuem outras características em comum: seus autores são escritores profissionais que atuaram na imprensa e que já publicaram livros; os jornalistas relatam suas memórias e nelas incluem suas passagens pela revista Realidade e pela imprensa alternativa; há uma recorrente menção à história individual como história vivida em conjunto e assim é frequente o uso do pronome "nós". Essa memória coletiva aparece associada à história da imprensa e também à história nacional, o que justifica que um amigo biografe o outro ou escreva sobre a revista. Cabe sublinhar que tais características remontam às especificidades do gênero reportagem, a saber, a exploração de marcas autorais e o registro indistinto da história vivenciada pelo repórter e a história coletiva.

O livro de Mylton Severiano exemplifica essa característica. Em Realidade - a revista que virou lenda, o fio condutor dos capítulos é a trajetória do grupo e das pessoas que estavam nos bastidores da revista enquanto ela conquistava alcance nacional. Mylton entrevistou seus colegas e teve acesso ao arquivo pessoal do redator-chefe Paulo Patarra. Na redação do livro de Severiano a respeito da revista Realidade, o autor lançou luz sobre os produtores da publicação ao abordar suas origens, formação intelectual, laços familiares, sociais e profissionais. Severiano, por repetidas vezes, classifica os colegas como indivíduos que no transcorrer nos anos marcaram suas trajetórias pelo exercício profissional da escrita no jornalismo e em muitos casos na literatura.

Quanto aos relatos autobiográficos, é preciso acrescentar que para apreciá-los em sua integridade faz-se necessário o reconhecimento da função exercida pela autoria. Ao narrarem suas reminiscências, esses profissionais estão ao mesmo tempo remetendo-se a outros discursos memorialísticos e demarcando suas identidades por meio da edificação de um "nome próprio" (Chartier, 2012a: $27)^{6}$. Tais narrativas devem ser igualmente coerentes tanto com a singularidade do nome próprio que pretendem demarcar como em relação ao discurso do jornalista intelectual e escritor. Dessa maneira, quando um amigo biografa o outro com a autoridade de um companheiro de viagem, falando em nome de uma geração - tal como Mylton Severiano em sua biografia sobre o escritor e amigo João Antônio -, temos aí uma consonância de narrativas: a do biógrafo, do biografado e do grupo. A coerência deixa entrever a "voz do grupo" que reivindica sua história e as incongruências descortinam até mesmo possíveis conflitos

6 A denominada "função autor" é resultado de estratégias textuais que vinculam a unidade e coerência de alguns discursos - como, por exemplo, o discurso jornalístico da grande reportagem - e um dado sujeito, nesse caso, intelectuais que na condição de jornalistas redigem obras híbridas que fundem realidade histórica e vida pessoal (Chartier, 2012a). 
internos e externos. As contingências da produção da memória estão implícitas nas características das obras biográficas e memorialísticas dos precursores da revista Realidade. $\mathrm{O}$ olhar retrospectivo do jornalista que conta sua história é capaz de demonstrar a remissão à identidade consagrada. As obras em questão reverenciam e reproduzem esse padrão.

Ao contrastar o percurso profissional e intelectual dos jornalistas referidos com as mudanças ocorridas na produção cultural posso inferir que as mudanças no mercado profissional dos jornalistas possuem relação intrínseca com a crescente onda de publicações de memórias de antigos jornalistas. É possível inferir os vínculos entre as concepções de identidade e memória jornalística. $\mathrm{O}$ crescimento do número de produções históricas a respeito dos nomes e veículos da imprensa indica as mudanças ocorridas no campo, com o envolvimento da crise de identidade profissional, e as mudanças no mercado profissional. Elas demarcam um entendimento e uma forma de legitimação que estão em vias de desaparecimento por estarem em confronto direto com as novas formas de recrutamento e ascensão às posições de proeminência no mercado profissional jornalístico. Tal situação pressupõe uma mudança na modalidade de registro da história do jornalismo, uma vez que a articulação entre memória individual e memória coletiva deixou de ser algo restrito ao gênero da reportagem. Nas últimas décadas, os registros das experiências e trajetórias dos jornalistas considerados exemplares tem se confundido com a própria narrativa da história da imprensa (Bergamo, 2011: 257). O que se mostra é o conflito entre duas formas de registro da memória, o primeiro por meio das reportagens e o segundo pelo registro histórico dos casos consagrados. A transformação da memória em história encerra a forma como os jornalistas se veem e intencionam serem vistos. É preciso considerar as descontinuidades dos registros da história da imprensa. Se antes as reportagens publicadas em jornais e revistas eram acervos de registro histórico, atualmente o destino desse tipo de produção são os livros-reportagens e de memórias.

Finalmente, um último traço característico dessa produção memorialística trata-se do resgate das trajetórias dos integrantes da equipe original e dos laços de sociabilidade constituídos ao longo das carreiras e que mantiveram os participantes relativamente unidos. Tais narrativas são encontradas nos livros Realidade Re-vista, de José Hamilton Ribeiro e José Carlos Marão, e Realidade - a revista que virou lenda, de Mylton Severiano. No livro memorialístico de Severiano, em especial, a origem social de cada um é retomada de modo a ressaltar que a maioria dos integrantes do grupo é constituída por indivíduos oriundos da região Sudeste, em geral do Estado de São Paulo, especialmente de 
municípios do interior. Embora haja casos de indivíduos que vieram de Minas Gerais (Frei Betto) e também da região Nordeste (Eurico Andrade). Entre eles, dois vieram da mesma cidade e começaram a vida profissional juntos em auxílio mútuo na conquista de oportunidades de trabalho, como Mylton Severiano e Woile Guimarães. Em geral, tiveram boa educação e acesso a livros e outros produtos culturais. Há casos de trajetórias pessoais em que o indivíduo possui parte da família na capital e parte da família no interior (Carlos Azevedo), ou seja, pode-se dizer que a equipe inicial da revista Realidade era formada, em geral, por indivíduos que tinham alguma familiaridade com as produções culturais dos centros urbanos e as referências à cultura popular brasileira podem ser conferidas tanto nas reportagens da revista Realidade quanto na produção biográfica e memorialística de seus jornalistas.

\section{Origens e trajetórias sociais heterogêneas}

A formação cultural dos jornalistas em questão e os primeiros contatos com a cultura escrita não foram homogêneos. Com base nas origens geográficas, é possível dividir o grupo em interioranos e citadinos. Os interioranos são aqueles que foram escolarizados e viveram até a adolescência em municípios do interior; os citadinos são aqueles que receberam formação escolar nas grandes capitais.

Citadinos como Roberto Freire, João Antônio e Frei Betto apresentam em comum o fato de terem tido acesso às informações culturais e artísticas desde a infância no ambiente familiar. $\mathrm{O}$ ambiente urbano lhes propiciou o contato com a produção cultural, com escritores, músicos, artistas e intelectuais.

O médico, psicanalista, escritor e jornalista Roberto Freire nasceu e foi educado em uma família de classe média da capital paulista. Ele relata em sua biografia a importância de um amigo próximo no estímulo à sua formação intelectual e artística. Por meio desse amigo, cujo pai era membro da Academia Paulista de Letras, pôde conhecer pessoalmente escritores e artistas, como Monteiro Lobato, Mário de Andrade e Oswald de Andrade. As conversas com esses autores ainda na adolescência motivaram o gosto pela produção cultural, pela política e também a vontade de se tornar escritor. No entanto, por exigência da família, formou-se em medicina na Universidade Federal do Rio de Janeiro. No curso, foi aluno do professor Carlos Chagas, que o introduziu na pesquisa científica e o auxiliou a realizar a primeira viagem internacional. Por meio de uma bolsa de estudos concedida pela Unesco, ficou por um ano no Collège de France, período em que apurou sua inclinação para a literatura e começou seus estudos sobre psicologia. De volta ao Brasil, Roberto Freire se envolveu inicialmente com trabalhos 
na área de psicoterapia e em seguida iniciou a carreira multifacetada, que foi o seu traço característico. É reconhecido como escritor, ex-jurado de festivais musicais, dramaturgo, jornalista e fundador da Soma Terapia (Freire, 2002b).

Tal como Roberto Freire, Frei Betto acumulou, ao longo da vida, diferentes inclinações vocacionais. Além de ter atuado como jornalista nas décadas de 1960 e 1970, é vinculado à ordem dominicana. Como religioso - junto com Leonardo Boff -, é um dos expoentes da Teologia da Libertação no Brasil, sendo militante em vários movimentos sociais e pastorais. Frei Betto nasceu e viveu até a adolescência em Belo Horizonte, Minas Gerais, e estudou nos colégios Marista e Aplicação. Aos 13 anos, o futuro escritor ingressou na Ação Católica e ao final da adolescência foi para o Rio de Janeiro indicado para a direção da Juventude Estudantil Católica, período em que ingressou no curso de jornalismo da Universidade Federal do Rio de Janeiro. Sua mudança para São Paulo aconteceu quando foi admitido na Ordem Dominicana para fazer o noviciado, momento em que abandonou o curso de jornalismo e começou sua colaboração para jornal Brasil Urgente, dirigido pelo Frei Carlos Josaphat. O jornal Brasil Urgente uniu Frei Betto e Roberto Freire. A amizade com Freire favoreceria pouco tempo depois a passagem do então noviço Carlos Alberto Libânio, o Frei Betto, pela mais prestigiada revista brasileira da década de 1960, a revista Realidade (Betto apud Moraes, 2010: 194).

Ao fim dos anos 60, a revista reuniu outros aspirantes à profissão de escritor e escritores já reconhecidos, como João Antônio. Após o período de Realidade, o escritor trocou correspondências durante décadas com o colega Mylton Severiano que, após a morte de João Antônio, publicou uma biografia sobre o amigo. Nela, consta que João Antônio nasceu em uma região entre a capital paulista e Osasco, "filho de mãe carioca emigrada para São Paulo e um pai português (...) João Antônio pai, crescido e alfabetizado na França, gostava de ler e João Antônio Filho tornou-se leitor voraz" (Severiano, 2013e: 233).

Mylton relata que o precoce João Antônio publicou um conto aos 13 anos no jornal $O$ crisol, no qual debutou no jornalismo. Aos 18 anos já trabalhava em agências de publicidade e, após atuar como repórter do caderno de cultura do Jornal do Brasil, foi para a redação da revista Realidade. Nesse momento, tinha 30 anos e já era um escritor laureado com o prêmio Fábio Prado por original inédito e dois prêmios Jabuti nas categorias de autor revelação e de melhor livro de contos (Severiano, 2013e: 233). João Antônio, posteriormente, desenvolveria em Realidade o gênero conto-reportagem. Foi um escritor que obteve reconhecimento imediato da crítica literária logo após a estreia com Malagueta, Perus e Bacanaço, em 1963. Enaltecido pelo emprego da linguagem coloquial e por dar 
protagonismo aos párias sociais em seus contos, tinha fixação por outro jornalista e escritor que exercia forte influência sobre o seu trabalho. Ao escritor Lima Barreto dedicou vários livros, a começar por Malagueta, Perus e Bacanaço, no qual se pode ler a dedicatória: "Para Afonso Henrique de Lima Barreto, pioneiro, Paulo Ronái, Mário da Silva Brito e Daniel Pedro de Andrade Ferreira - meu filho". A dedicatória lembra seu filho, os padrinhos, Ronái e Brito, escritores e jornalistas que o ajudaram no início da carreira literária e o escritor Lima Barreto, a quem qualifica como "pioneiro". Tendo em mente que Lima Barreto foi um escritor que abordava de forma irônica a elite política e cultural de seu tempo e dava visibilidade às figuras socialmente marginalizadas, pode-se conjecturar que João Antônio creditava a si mesmo o papel de herdeiro do legado de Lima Barreto. A afeição pelo escritor carioca o levou inclusive a produzir um romance histórico, Calvário e Porres do Pingente Afonso Henrique de Lima Barreto, lançado em 1974, pela Editora Civilização Brasileira. Em comum, Lima Barreto e João Antônio compartilhavam a posição de escritores malditos em suas respectivas épocas. Ao redigir um romance biográfico sobre Lima Barreto, João Antônio realiza ao mesmo tempo dois feitos importantes: reitera o prestígio do seu ídolo literário e enlaça sua trajetória intelectual à do escritor carioca (Miceli, 2009). Posteriormente, a construção da história desse grupo de jornalistas da revista Realidade foi levada adiante pelo amigo Mylton Severiano, que produziu a biografia intitulada Paixão de João Antônio. A biografia do escritor paulistano também consagra o nome de Severiano à medida que conjuga as duas trajetórias intelectuais no registro histórico da produção cultural nacional.

É em Paixão de João Antônio que Mylton começa a tecer o registro histórico do grupo de jornalistas junto ao nome da revista Realidade e a publicá-lo em livros. Ainda na mesma biografia descreve a impressão de João Antônio sobre o período da revista:

A revista que nos transformou em "grifes", no dizer de Paulo Patarra, e que ainda em 2005 levava estudiosos a procurar os "sobreviventes" para compor suas teses em cursos de comunicação, cobrou preço alto a JA [...] Para ele, não havia nada de 'anos loucos', a não ser 'o tamanho da grana que os patrões ganhavam com o nosso talento, sacrifício, noites sem dormir, serões na redação e frustração geral' (Severiano, 2005: 59).

João Antônio manteve um contato estreito com a imprensa desde o início da carreira. Foi em um jornal infanto-juvenil que publicou seus primeiros textos (Severiano, 2013e: 233) e foi por meio dos jornais que difundiu grande parte de sua obra literária anos mais tarde. Ao longo de sua carreira, o escritor se 
dedicou obstinadamente a manter uma rede de contatos com escritores, intelectuais e editores. Extensas cartas enviadas a jornalistas garantiram a difusão de sua obra no círculo artístico e também o ingresso como repórter especial do segundo caderno do Jornal do Brasil no início dos anos 6o, na época um dos mais importantes do Brasil a aglutinar escritores e intelectuais (Lacerda, 2006).

A entrada precoce no ofício jornalístico e a publicação de textos em pequenos jornais ainda na infância ou na adolescência não é algo restrito a João Antônio, embora seja o único caso entre os citadinos. A menção à publicação precoce em pequenos jornais está vinculada à ideia de que o jornalismo é algo inato a esses profissionais da escrita. Os jornalistas aqui considerados segundo a origem e trajetória social como interioranos mencionaram essa passagem em suas memórias, como José Hamilton Ribeiro e Mylton Severiano.

José Hamilton Ribeiro é natural de Santa Rosa do Viterbo, nordeste paulista. José Hamilton conta que uma tia, dona da única livraria da cidade, havia lhe apresentado na infância obras do Monteiro Lobato e o estimulara a publicar um texto em um jornal produzido em um colégio de padres na cidade de Manhumirim chamado O Lutador (Hamilton apud Moraes, 2010: 166). Nos anos seguintes, José Hamilton fez o curso ginasial em São Simão e Ribeirão Preto e foi para São Paulo cursar jornalismo e trabalhar (Severiano, 2013e: 254). Destino semelhante teve o colega de Realidade, Mylton Severiano.

Mylton nasceu em Marília, município do interior de São Paulo, onde foi escolarizado primeiramente com a ajuda da família e amigos próximos antes de ingressar no sistema educacional para concluir o ensino médio e um curso de música em um conservatório da região. Assim como José Hamilton, Mylton também se recorda de ter "debutado" ainda jovem nos jornais por influência de uma figura familiar. O pai de Severiano enviou uma redação do filho para que fosse publicada no jornal Terra Livre, vinculado ao Partido Comunista.

No que diz respeito às trajetórias profissionais, é notável a diferença entre as origens e os percursos entre citadinos e interioranos. Frei Betto, João Antônio e Roberto Freire, os citadinos, deixaram entrever em suas narrativas um índice relevante de capital cultural incorporado via ambiente familiar (Bourdieu, 1999: 72). Os pais de Frei Betto exerciam profissões intelectuais. Os de Roberto Freire pertenciam à classe média e mantinham hábitos culturais internalizados pelo filho aspirante a escritor. A família de João Antônio, embora não tivesse condições econômicas e culturais para provê-lo em sua carreira intelectual, tinha como diferencial a figura paterna. O pai do escritor fora educado na França e da educação no continente europeu lhe restou a inclinação para as artes que se manifestavam no apreço pela leitura e pela música. Era violonista, participava 
de grupos de Choro e em suas viagens para reencontrar parceiros sempre levava o filho mais velho, João Antônio. Certamente essa ascendência influenciou na vocação artística do escritor paulista.

Experiência diferente teve o jornalista Carlos Azevedo. Leitor de Monteiro Lobato e de histórias em quadrinhos na infância, Carlos Azevedo nasceu em São Paulo, capital, mas foi criado no Pontal do Paranapanema. Em sua biografia, o jornalista conta que viveu a infância entre o campo e a cidade: "assim me criei, um híbrido, longe de ser um cosmopolita, mas com algumas influências da cultura da capital, e nem um rapaz do campo autêntico, em que pese a vivência da roça. Meio caipira, meio urbano" (Azevedo, 2007a: 328).

José Carlos Marão, Woile Guimarães, José Hamilton Ribeiro, Carlos Azevedo e Mylton Severiano foram para a capital estudar a fim de se ingressarem em uma universidade. Como não tinham condições para se sustentarem, começaram a trabalhar como jornalistas. Ao fim, a maioria ingressou na universidade, porém, não concluíram o curso superior, pois o trabalho como jornalistas parece ter suprido a necessidade de ascensão profissional e até de formação intelectual (Azevedo apud Moraes, 2010: 174). Este grupo personifica a trajetória dos jornalistas que aqui chamo de interioranos, aqueles que nasceram ou viveram a infância em municípios do interior do país, foram escolarizados em escolas municipais ou rurais e receberam a influência de algum parente em sua educação. Em suas trajetórias, a ida para a capital simbolizava a oportunidade de ingressar em uma carreira intelectual, o que ocorreu ao se dirigirem para o jornalismo.

Para os jornalistas nascidos no interior não havia a chance de circularem em ambientes que favorecessem o desenvolvimento na carreira intelectual, embora houvesse o incentivo ao consumo cultural no meio familiar. A chance de progresso profissional vinculava-se à conquista de um título universitário. Nos depoimentos, a justificativa para a mudança para a capital era com a finalidade de estudar para ingressar em um curso superior. $O$ jornalismo se tornou uma forma de remuneração inicial e de entrada no mercado de trabalho intelectual. Para os jornalistas que haviam ingressado em grandes veículos, como o jornal $O$ Estado de São Paulo ou nas publicações da Editora Abril, por meio de suas redes de relação (indicação de algum amigo próximo à família, por exemplo), o jornalismo parecia ser suficiente para a ascensão em uma função intelectual especializada, já que na época não havia a exigência do diploma para exercício do jornalismo.

É necessário destacar que muitos dos citados se beneficiaram de um momento em que várias empresas de comunicação eram incipientes ou estavam em fase de ascensão, como a Abril, editora de Realidade, por exemplo. Nessas empresas os jornalistas mencionados constituíram laços apoiados no coleguismo 
e nas afinidades político-ideológicas. Outros, porém, eram amigos de infância, como Mylton Severiano e Woile Guimarães.

Woile foi amigo de infância. Tinha eu três anos e ele cinco quando as famílias ficaram vizinhas em Marília, eles de Guararapes, no Noroeste do Brasil, ligação com Mato Grosso. Brincamos no quintal, fomos colegas de estudos, jogamos - eu ponta esquerda, ele goleiro da União Infantil de Vila Barbosa. Cuidamos do Uirapuru, jornal do Grêmio. Seguimos para a capital, para uma faculdade que nenhum dos dois concluiria. Ele em 1959, com a carta do pai para o amigo que trabalhava na Folha. Woile me abriu a porta da Folha em 1960, eu lhe abri a porta da Abril em 1965 (Severiano, 2013e: 292).

Com exceção de Severiano, a maior parte dos entrevistados iniciou na profissão em jornais menores do interior, em geral, a convite de um amigo. Então, assim começaram a expandir suas redes de contatos. As afinidades ideológicas em um momento de acirramento do debate político, na primeira metade da década de 1960, pode ter contribuído para a aproximação de vários desses profissionais. Vale acrescentar que a greve dos jornalistas ocorrida em 1961 é recordada como marco de um momento de união corporativa para muitos deles. Cumpre salientar que o acionamento do capital social da rede de relacionamentos é silenciado e interpretado como camaradagem pela maioria.

A experiência na revista Realidade e na imprensa alternativa aparece como marco temporal em muitos dos relatos. As datas das publicações dos livros de memórias e das biografias coincidem com um momento de crise e de redefinição da identidade jornalística. A questão da exigência de diploma para exercer a profissão transparece como marco temporal escamoteado, embora presente na defesa do autodidatismo no depoimento de Severiano.

Eis um flagrante da turma: andar de ônibus devorando letras. Autodidatas [...] Não havia exigência do diploma para exercer o jornalismo. Realidade não teria sido possível se já existisse essa invencionice, gestada no auge da escalada fascistoide da ditadura. Quase todos éramos filhos de classe média baixa ou da pobreza. Havia filho de ferroviário, telefonista desquitada, professor, sapateiro, comerciante, barbeiro, chofer de praça, contador, funcionário público. Vários trabalhavam em banco e, no fim do expediente partiam para a vocação (Severiano, 2013e: 26).

Dos registros biográficos dos jornalistas da extinta revista Realidade emergem referências a um passado extraordinário no qual integraram a equipe fundadora de um projeto editorial que estava em sintonia com um tempo de 
efervescência revolucionária. Contudo, é necessário considerar primeiramente o fato de que tais biografias e memórias foram publicadas a partir dos anos 2000, uma década em que Realidade já detinha o título de publicação "emblemática da história da imprensa brasileira"?. Em segundo lugar, as transformações no mercado profissional aparecem de forma latente como as mudanças ocorridas nas formas de recrutamento e ascensão no jornalismo, por exemplo. Essas transformações foram marcadas pela exigência do diploma a partir de 1969, fator que possivelmente interveio nas estratégias tradicionais de acesso à carreira jornalística que estão associadas aos recursos da origem social e geográfica, o peso das redes de relações pessoais e a militância política (Petrarca, 2007b). Essas transformações foram a motivação para o surgimento de um conflito entre duas gerações de jornalistas, aqueles que conquistaram o seu espaço nas redações pela experiência vivida durante as décadas de 1960 e 1970 e aqueles que se formaram nas universidades a partir dos anos 1980 e 1990. A marca da segunda geração seria o diploma e a expertise técnica e a marca da primeira geração seria o posicionamento crítico.

\section{Repertório e estilo de escrita: uma formação impressa nas páginas de livros e revistas}

A referência a um modelo de jornalista associado à literatura e à militância política que se fazem presentes na produção memorialística dos jornalistas também pode ser identificada por meio do exame da produção jornalística desses autores. Nela se sobressaem a formação literária e política dos jornalistas que compuseram a primeira redação de Realidade. Tal formação repercutiu na forma de cobertura dos assuntos pautados pela publicação. Jorge Amado, por exemplo, é considerado por muitos como leitura obrigatória. $\mathrm{O}$ escritor baiano é autor de $O$ cavaleiro da esperança, biografia de Luís Carlos Prestes publicada pela Editorial Vitória, em 1956. Amado também dirigiu a coleção Romances do Povo (1954-1956), publicada pela referida editora. As obras de Jorge Amado serviram de inspiração para produção de muitas das reportagens de Realidade, tanto na temática quanto no que se refere à linguagem, como se verificou nas reportagens Um despacho de amor, de Narciso Kalili (publicada em abril de 1966), e Meninos do Recife, de Roberto Freire (agosto de 1967), reportagem que

7 A memória é seletiva, pois nem tudo fica gravado ou registrado. Ela sofre flutuações em função do momento em que é articulada. As preocupações do momento constituem um elemento de estruturação da memória. Isso vale tanto para memória individual como para a coletiva, tal como a memória nacional que constituiu um objeto de disputa constante. Em suma, a memória é uma construção que sofre influência das preocupações pessoais e políticas do momento (Pollak, 1992: 4). 
remetia à história do romance Capitães da Areia, de Jorge Amado, e que rendeu o prêmio Esso de reportagem a Freire.

É possível inferir que muitos dos títulos de reportagens publicadas na revista Realidade foram inspirados por essa leitura de matiz política ${ }^{8}$. Artigos traduzidos e publicados pela revista Vanguarda Socialista, da Gráfica-Editora Unitas, em 1946, como A revolução russa, de Rosa Luxemburgo, e a A revolução chinesa (Karepovs, 2013b: 116), assemelham-se à matéria de Mylton Severiano feita para a edição de março de 1967, também intitulada $A$ revolução russa; assim como as matérias $A$ dor do parto não existe, de janeiro de 1967, assinada por Carlos Azevedo, e Os dez dias da criação, com fotos que acompanhavam o desenvolvimento de um feto antes do nascimento. Todas são matérias que parafrasearam títulos de livros lançados em 1956 pela Editorial Vitória: $O$ parto sem dor e $A$ origem da vida (Maués, 2013c: 142). Isto é, apesar de não se exibir de forma clara nas páginas da revista Realidade, o imaginário militante que circulava entre os integrantes do grupo, o conjunto de leituras provenientes das publicações políticas estava presente como influência na publicação.

Também foram publicados assuntos que estavam na ordem do dia nas discussões dos intelectuais de esquerda na época, como a descoberta do Brasil "continental" e interiorano e as principais mazelas do povo brasileiro. A reportagem feita por José Hamilton Ribeiro De que morre o Brasil? (janeiro de 1968) é uma paráfrase empregada pelo possível leitor de Cadernos do Povo Brasileiro - o jornalista Paulo Patarra, editor-chefe da revista - que no volume 16, de 1963, publicava De que morre o nosso povo? de autoria de Aguinaldo Nepomuceno Marques (Lovatto, 2013d, p. 156).

Provavelmente, a equipe que lançou Realidade era leitora dos Cadernos do Povo Brasileiro, uma das publicações mais combativas até 1964. Editado pela Civilização Brasileira sob a coordenação do jornalista e intelectual Ênio da Silveira, os Cadernos do Povo Brasileiro tratavam de temas nacionais e polêmicos para a época, porém, de uma forma simples a fim de facilitar a difusão do material a um amplo espectro de público. As edições eram encabeçadas por títulos explosivos e na forma de interrogação, como Quem é o povo brasileiro? (1962), Quem faz as leis no Brasil? (1962), Quem dará o golpe no Brasil? (1962), O que éo

8 Entre a década de 1930 até o período pré-1964, estabelecimentos como a Gráfico-Editora Unitas (1930-1934), a Editorial Vitória (1944-1964) e a Editora Civilização Brasileira (1962-1964) publicaram obras literárias e políticas que eram diretamente ou indiretamente vinculadas aos autores marxistas. Tal estratégia era tributada às deliberações do Partido Comunista, cujas ramificações se expandiam por várias partes do mundo no começo do século XX, orientadas pela agitprop, estratégia de agitação e propaganda gestada por jornalistas, intelectuais e artistas do Partido Comunista (Deaecto; Mollier, 2013a: 15). 
imperialismo? (1963), O que é a constituição? (1964), Desde quando somos nacionalistas? (1963) (Lovatto, 2013d: 153). Esses títulos poderiam estar em Realidade sem destoar da linha editorial da publicação, uma vez que nela se encontram indagações e títulos tão explosivos quanto as enquetes seguintes: Existe racismo no Brasil? (junho de 1967), Você é contra ou a favor da educação sexual? (julho de 1968) e É verdade que o Brasil está nas mãos dos militares? (janeiro de 1968). Em grandes reportagens, o modelo também era empregado como nos títulos: Quanto custa o Brasil?, De Eurico da Andrade, publicada em abril de 1968; Como o congresso pensa (e como pensaria se votasse)?, de Carlos Castelo Branco (dezembro de 1968); e Revolução na Igreja, de autoria de Narciso Kalili (outubro de 1966). Nesse caso, a reportagem parece responder a uma pergunta feita na edição de 1963, de Cadernos do Povo Brasileiro, A igreja está com o povo? Na revista Realidade são mostrados muitos noviços (incluindo Frei Betto) que diziam estar ao lado do povo. Como é possível notar, a literatura de esquerda era parte significativa de uma formação autodidata no jornalismo exercido pelos profissionais da revista Realidade.

Tanto na produção memorialística e autobiográfica como na produção jornalística é reiterado o modelo do jornalista escritor e cronista social, o profissional jornalista que além de escritor não se isenta de pensar a realidade nacional. Deduzo que a motivação em desvelar os problemas e trazer à tona as questões nacionais remonta a um autor citado como referência pelos entrevistados, Monteiro Lobato. $\mathrm{O}$ escritor e jornalista Roberto Freire relata em sua autobiografia a sua formação intelectual e o encontro com Lobato durante a infância na casa de um amigo:

...à noite, em sua casa, pude conhecer alguns dos principais intelectuais de São Paulo naquela época, como Mário de Andrade, Guilherme de Almeida, Menotti Del Picchia, Oswald de Andrade e Monteiro Lobato. O encontro com Monteiro Lobato foi algo fundamental e inesquecível. Impressionava-me muito ver de perto o escritor que mais admirava e de quem havia lido toda a obra publicada até aquela época. Seus livros complementavam meus conhecimentos rudimentares sobre humanidades ensinadas na escola e, sobretudo, agradava-me demais seu estilo bem humorado e crítico... (Freire, 2002b: 26)

Freire, conjuntamente com Paulo Patarra, foi considerado um dos mentores das grandes ideias que surgiram em Realidade e exercia forte influência sobre os demais. Não coincidentemente, sua admiração pela obra de Monteiro Lobato é citada como referência na formação intelectual em todas as entrevistas concedidas e constam nas memórias publicadas em livro. Mylton Severiano fez 
uma série de entrevistas com os amigos para redigir o livro lançado em 2013 sob o título Realidade - a revista que virou lenda. Quando perguntado a respeito de sua formação intelectual, Mylton cita Lobato como uma referência comum a todos: "Monteiro Lobato é recorrente. Entrevistei todos os sobreviventes, praticamente, por causa do livro. Invariavelmente, na infância, Monteiro Lobato. Bom texto, mordaz. A Emília era o Lobato. Havia o espírito questionador" (Severiano apud Moraes, 2010: 144). O depoimento de Carlos Azevedo corrobora o do colega.

Carlos Azevedo relatou em entrevista que por meio da obra de Lobato começou verdadeiramente sua formação intelectual, já iniciada com a leitura de histórias em quadrinhos, revistas como $O$ Cruzeiro e idas ao cinema. Nos anos 50, a Editora Ebal publicava uma edição mensal chamada Edições Maravilhosas, que reproduzia em quadrinhos a história de algum romance consagrado. Assim, teve acesso a obras como: O corcunda de Notre Dame, de Victor Hugo, e O conde de Monte Cristo, de Alexandre Dumas. A descoberta dos clássicos da literatura, como Hemingway, Maupassant, Émile Zola, Guimarães Rosa, aconteceu após os 20 anos, depois da mudança para São Paulo. Para Azevedo, a vivência proporcionada pelo jornalismo auxiliou em sua formação, enquanto o autodidatismo fez dele alguém "com conhecimento de mundo" (Azevedo apud Moraes, 2010: 174).

É curioso notar que apesar da ênfase dada à formação intelectual autônoma, alguns já haviam passado pelos bancos universitários, Roberto Freire era formado em medicina; João Antônio concluiu o curso de jornalismo na Cásper Líbero antes de ingressar no Jornal do Brasil; José Hamilton Riberio, Paulo Patarra e Frei Betto haviam passado pelo curso de jornalismo sem concluírem-no, o primeiro inclusive é formado em Direito; e o próprio Mylton Severiano havia cursado dois anos de Direito, tendo ao final optado pelo jornalismo.

No caso dos jornalistas entrevistados, é recorrente a transmutação do fracasso em carreiras cuja ascensão se faz tradicionalmente via diploma em sucesso profissional, o que explica o discurso de sagração do autodidatismo. A defesa do autodidatismo em contraposição à titulação escolar para admissão e formação profissional aparece escamoteada na defesa de Mylton Severiano a respeito da vocação inata ao jornalismo:

Todos gostavam de ler. Eram autodidatas. Graças a Deus não havia a exigência do diploma. A revista não seria possível. Hamilton Almeida Filho, por exemplo, um dos melhores repórteres que eu já vi na minha vida, começou a trabalhar aos quinze anos, no jornal carioca $A$ noite, hoje extinto. 
Se houvesse a exigência do diploma, como um cara como esse faria? (...) Jornalista é vocação, é como ser pintor, escritor, poeta... Como você pode pedir a um poeta: deixe-me ver seu diploma de poeta? (Severiano apud Moraes, 2010: 144)

Há no comentário de Severiano explicitação de uma ideia que se assemelha ao posicionamento de Frei Betto sobre o tema: "Um bom jornalista não se faz com diploma, e sim com talento, sobretudo o investigativo, e com ética, não vender a alma ao diabo em função de promoções e salários. Jornalismo é uma arte e artista não precisa de diploma”. Destaca-se que essa afirmação se associa à ideia de jornalismo como algo inato e funciona como outras expressões correlatas do imaginário jornalístico, como "faro" jornalístico para designar que um profissional sabe instintivamente o que é notícia.

O estudo dos registros memorialísticos torna perceptível também as transformações no mercado profissional que originou novas formas de recrutamento e ascensão na carreira. Percebe-se que o jornalismo se tornou progressivamente mais técnico. Uma linguagem específica se consolidou, distinguindo-se da literatura e do discurso político. A entrada na profissão se tornou dependente do diploma ao mesmo tempo em que a militância enfraqueceu como valor que pudesse ser associado ao jornalismo praticado, fazendo com que os novos jornalistas fossem considerados desprovidos de crítica pelos antigos jornalistas. Os jornalistas de Realidade se contrapõem a essa nova concepção de jornalismo e essas transformações no contexto da produção dos registros biográficos são aqui analisadas. Foi estabelecido o conflito entre duas concepções de jornalismo que passaram a conviver simultaneamente e com duas formas distintas de ingresso e conquista de prestígio na carreira. Uma delas, associada ao acionamento do capital social relacionado à rede de relações, à militância política e à origem social e, a outra, associada ao título universitário e à formação técnica.

Portanto, poder-se-ia dizer que os relatos memorialísticos de jornalistas em questão retratam o contexto social e histórico em que foram escritos, a saber, um momento de conflito entre duas identidades profissionais contrapostas. Tais registros corroboraram para a edificação e o fortalecimento de um modelo de profissional em vias de extinção. Este modelo profissional traduz a ideia do jornalista que conjuga o trabalho na imprensa com outras formas de atuação, seja na literatura, seja no engajamento político. A imagem do jornalista combativo, cronista social e aspirante a escritor, ainda que esteja cristalizada na historiografia da imprensa brasileira por meio de nomes como Machado de Assis e Lima Barreto, tornou-se mais incisiva nas décadas de 1990 e 2000, período marcado por intensas 
transformações e conflitos no mercado profissional jornalístico. Sendo assim, as produções culturais - memorialísticas, biográficas, jornalísticas e científicas -, ancoradas no modelo aqui referido, são resultado do momento histórico em que vieram à tona e por isso trazem consigo as marcas dos conflitos de seu tempo.

\section{Referências}

ANTÔNIO, João. Malagueta, Perus e Bacanaço. São Paulo, Cosac Naify, 2004 (222).

AZEVEDO, Carlos. Cicatriz da reportagem: 13 histórias que fizeram um repórter. São Paulo, Editora Papagaio, 2007 (404).

BERGAMO. A escrita do presente: mudanças no status cultural do jornalismo. In: MICELI, Sérgio;

PONTES, Heloísa (Org.). Cultura e Sociedade. São Paulo, Ed. Edusp. 2014, pp. 214-239. . Reportagem, Memória e História no Jornalismo Brasileiro. Mana [online], 2011, v.17, n.2, pp. 233-269. ISSN 0104-9313. Disponível em: <http://dx.doi.org/10.159o/ So104-93132011000200001>. Acesso em: 10 set. 2019.

BOURDIEU, Pierre. Os três estados do capital cultural. In: CATANI, Maria Alice; CATANI, Afrânio (org.). Escritos de Educação. Petrópolis, RJ, Vozes, 1999. pp. 71-79. CHARTIER, Roger. O que é um autor? Revisão de uma genealogia. São Paulo, EdUFSCar, 2002 (90).

DEAECTO, Marisa Midori. A batalha do livro. In: DEAECTO, Marisa Midori; MOLLIER, Jean-Yves. Edição e Revolução - leituras comunistas no Brasil e na França. Belo Horizonte, Minas Gerais, Editora UFMG, 2013, pp. 13-25.

FREIRE, Roberto. Eu é um outro: autobiografia de Roberto Freire. Salvador, Maianga, 2002 (452).

GRILL, Igor Gastal. "Memórias" de políticos brasileiros: produção escrita, gestão de imagens e "teorizações" nativas do jogo político. Política e Sociedade. Florianópolis, V. 11, n. 22, 2012, pp. 11-40.

KAREPOVS, Dainis, A Gráfico-Editora Unitas e seu projeto Editorial de Difusão do Marxismo no Brasil dos Anos 1930. In: DEAECTO, Marisa Midori; MOLLIER, JeanYves. Edição e Revolução - leituras comunistas no Brasil e na França. Belo Horizonte, Minas Gerais, Editora UFMG, 2013, pp. 65-119.

LACERDA, Rodrigo. João Antônio: uma biografia literária. Tese de Doutorado, Teoria Literária e Literatura Comparada, USP, 2006.

LOVATTO, Angélica. Um projeto de Revolução Brasileira no Pré-1964: Os Cadernos do Povo Brasileiro. In: DEAECTO, Marisa Midori; MOLLIER, Jean-Yves. Edição e Revolução - leituras comunistas no Brasil e na França. Belo Horizonte, Minas Gerais, Editora UFMG, 2013, pp. 121-152. 
MAUÉS, Flamarion. A Editorial Vitória e a Divulgação das Ideias Comunistas no Brasil (1944-1964). In: DEAECTO, Marisa Midori; MOLLIER, Jean-Yves. Edição e Revolução - leituras comunistas no Brasil e na França. Belo Horizonte, Minas Gerais, Editora UFMG, 2013, pp. 121-152.

MICELI, Sérgio. A elite eclesiástica brasileira: 1890-1930. São Paulo, Companhia das Letras, 2009.

MORAES, Vaniucha de. Realidade (Re) vista: o papel do intelectual na concepção de um projeto revolucionário. Dissertação de Mestrado, Jornalismo, UFSC, 2010.

PETRARCA, Fernanda. O jornalismo como profissão: recursos sociais, titulação acadêmica e inserção profissional dos jornalistas do Rio Grande do Sul. Tese de doutorado, Sociologia, UFRGS, 2007.

POLLAK, Michael. Memória e identidade social. Estudos Históricos. 1992, v. 5, n. 10, pp. 200-212.

PONTES, Heloisa. Cidades e intelectuais: os "nova-iorquinos" da Partisan Review e os "paulistas" de Clima entre 1930 e 1950. Revista Brasileira de Ciências Sociais. São Paulo, v. 18, n. 53, outubro 2003, pp. 33-52.

RIBEIRO, José Hamilton. Jornalistas: 1937 a 1997: história da imprensa de São Paulo pelos que batalham laudas (terminais), câmeras e microfones. São Paulo, Imprensa Oficial do Estado, 1998 (243).

SEVERIANO, Mylton. Realidade - história da revista que virou lenda. Florianópolis, Insular, 2013 (318). Paixão de João Antônio. São Paulo, Editora Casa Amarela, 2005 (330).

\section{Reportagens da Revista Realidade}

ANDRADE, Eurico. Quanto custa o Brasil? Realidade. São Paulo, ano III, n. 32, Novembro 1967 , pp. $74-81$.

ANTÔNIO, João. Um dia no cais. Realidade. São Paulo, ano III, n. 30, Novembro 1968, pp. 98-112.

AZEVEDO, Carlos. A dor do parto não existe. Realidade. São Paulo, ano II, n. 15, Junho 1967 , pp. $150-157$.

CASTELO BRANCO, Carlos. Como pensa o congresso (e como votaria se pudesse?). Realidade. São Paulo, Dezembro 1967, pp. 26-32.

FREIRE, Roberto. Os meninos do Recife. Realidade. São Paulo, ano II, n. 17, Agosto 1967, pp. 24-30.

KALILI, Narciso. Um despacho de amor. Realidade. São Paulo, ano I, n. 1, Abril 1966, pp. 37- 43 .

Revolução na Igreja. Realidade. São Paulo, ano I, n. 7, Outubro 1966, pp. 34-43. 
RIBEIRO, José Hamilton. De que morre o Brasil? Realidade. São Paulo, ano. II, n. 22, Janeiro 1968, pp. 104-110.

SEVERIANO, Mylton. A revolução russa. Realidade. São Paulo, ano II, n. 11, Março 1967, pp. 131-141.

É VERDADE que o Brasil está nas mãos dos militares? Realidade. São Paulo, ano 1, n. 3, Junho 1966, pp. 22.

EXISTE racismo no Brasil? Realidade. São Paulo, ano II, n. 15, Junho 1967, p. 162.

VOCÊ É contra ou a favor da educação sexual? Realidade. São Paulo, ano III, n. 28, jul. 1968 , p. 48.

Recebido em: 27/03/2017

Aprovado em: 04/07/2019

\section{Como citar este artigo:}

MORAES, Vaniucha de. Reminiscência e Registro: um estudo da produção memorialística dos jornalistas da revista Realidade. Contemporânea - Revista de Sociologia da UFSCar, v. 9, n. 2, maio - agosto 2019, pp. 589-612. 